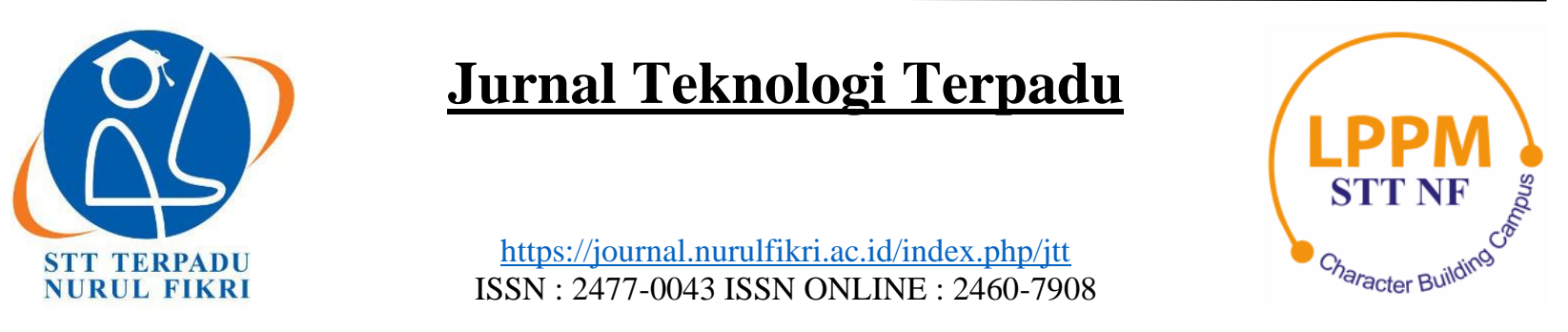

\title{
PENGEMBANGAN APLIKASI VIRTUAL TOUR SEBAGAI MEDIA PENGENALAN LINGKUNGAN KAMPUS PENS BERBASIS WEBSITE
}

\author{
Ashafidz Fauzan Dianta', Zakha Maisat Eka Darmawan², Zulhaydar Fairozal Akbar³, \\ Kholid Fathoni ${ }^{4}$
}

\author{
1,2,3,4 Departemen Teknologi Multimedia Kreatif, Politeknik Elektronika Negeri Surabaya \\ Surabaya, Jawa Timur, Indonesia 60111 \\ ashafidz@pens.ac.id, zakha@pens.ac.id, zfakbar@pens.ac.id, kholid@pens.ac.id
}

\begin{abstract}
The introduction of the New Student Campus Life (PKKMB) activity at The Electronics Engineering Polytechnic of Surabaya (EEPIS) is limited in its implementation due to the never-ending Covid-19 pandemic. All activities involving large numbers of people must carry out online to avoid the spread of the Covid-19 virus. With this policy, an application that can describe the campus life environment online is needed, so digital virtual reality media makes, namely Virtual Tour. The user interfaces in this application design using the Balsamiq application so that the resulting display is more attractive and interactive. A virtual tour application created using multi panoramic images, where $360^{\circ}$ panoramic images taken using a 360 camera taken at several campus locations - making a virtual tour application using the 3DVista application. The application development method used in this research is Multimedia Development Life Cycle (MDLC). From the test results of the website-based virtual tour application created, this application can display the environment and facilities owned by the EEPIS campus and can run according to its functionality, and can use by students to recognize the campus environment.
\end{abstract}

Keywords: virtual reality, virtual tour, website, images panorama 360, 3DVista

\begin{abstract}
Abstrak
Kegiatan Pengenalan Kehidupan Kampus Mahasiswa Baru (PKKMB) di lingkungan Kampus Politeknik Elektronika Negeri Surabaya (PENS) dibatasi pelaksanaanya, karena adanya pandemi Covid-19 yang tak berkesudahan. Saat ini seluruh kegiatan yang melibatkan banyak orang wajib dilakukan secara daring untuk menghindari penyebaran virus Covid-19. Dengan adanya kebijakan tersebut maka dibutuhan sebuah aplikasi yang dapat menggambarkan lingkungan kehidupan kampus secara online, maka dibuatlah media digital virtual reality yaitu Virtual Tour. User interface pada aplikasi ini dirancang menggunakan aplikasi balsamiq, sehingga tampilan yang dihasilkan lebih menarik dan interaktif. Aplikasi virtual tour yang dibuat menggunakan multi image panorama $360^{\circ}$, dimana pengambilan gambar panorama $360^{\circ}$ menggunakan kamera 360 yang diambil dibeberapa titik lokasi kampus. Pembuatan aplikasi virtual tour menggunakan aplikasi 3DVista. Metode pengembangan aplikasi yang digunakan dalam penelitian ini adalah Multimedia Develompent Life Cycle (MDLC). Dari hasil pengujian aplikasi virtual tour berbasis website yang dibuat, aplikasi ini dapat menampilkan lingkungan dan fasilitas yang dimiliki kampus PENS serta dapat berjalan sesuai dengan fungsionalitasnya dan dapat dimanfaatkan mahasiswa untuk mengenali lingkungan kampus.
\end{abstract}

Kata kunci: virtual reality, virtual tour, website, images panorama 360, 3DVista

\section{PENDAHULUAN}

Penyelenggaraan Kegiatan Pengenalan Kehidupan Kampus Mahasiswa Baru (PKKMB) Politeknik Elektronika Negeri Surabaya (PENS) dilakukan secara online atau daring dikarenakan saat ini berada pada situasi pandemi Covid-19. Pada kegiatan tersebut mahasiswa diberikan pemaparan materi mengenai bidang akademik, administrasi dan keuangan, kemahasiswaan serta kerjasama dan kemitraan. Pada saat pemaparan informasi mengenai lingkungan dan fasilitas kampus hanya sebatas foto dan video kegiatan tertentu dan belum mencakup tata letak lokasi yang mampu menggambarkan lingkungan dan fasilitas yang dimiliki kampus PENS.

Virtual Tour merupakan salah satu perkembangan teknologi digital yang dapat mensimulasikan lokasi berdasarkan realita dengan multi image panorama $360^{\circ}$ atau video $360^{\circ}$ serta dapat juga menggunakan model $3 D$ modeling [1]. Cara 
pengoperasian virtual tour terdapat dua cara, yaitu dengan akses melalui website atau dengan alat bantu virtual reality [2]. Pada dasarnya konsep virtual reality memiliki beberapa karakteristik antara lain: menampilkan lokasi secara berkelanjutan, tidak terpotong dan tanpa tepi dengan sudut pandang $360^{\circ}$ baik horizontal maupun vertikal [3].

Beberapa jurnal yang dijadikan referensi pada penelitian ini, diantaranya dilakukan oleh Rizal Bastian Nur Budi dkk dengan judul "Perancangan Virtual Kampus I UKSW sebagai Media Informasi Mahasiswa Baru" penelitian yang dilakukan pada tahun 2018 ini, aplikasi yang dibuat bertujuan untuk mempermudah mahasiswa baru dalam mengenali wilayah serta sebagai media informasi tentang letak gedung secara visual. Kesimpulan penelitian tersebut adalah dibutuhkan sebuah informasi tambahan pada tempat atau gedung, sehingga pengguna dapat mengenali fungsi dari tempat atau gedung tersebut [4]. Penelitian berikutnya dilakukan oleh Ridwan Nulhakim dkk dengan judul "Virtual Tour Pengenalan Area Universitas Siliwangi dengan Multi Image Panorama $360^{\circ}$ ", pada penelitian tersebut aplikasi virtual tour yang dibuat digunakan sebagai media pengenalan kampus Universitas Siliwangi. Dalam kesimpulan penelitian tersebut disarankan untuk menambah informasi dalam bentuk audio dan video agar informasi yang diberikan menjadi lebih detail dan jelas serta dibuat animasi dan transisi pergeseran tempat pada saat navigasi [5]. Achmad Choiron dkk. melakukan penelitian membuat aplikasi virtual tour berbasis website di lingkungan Universitas Dr.Soetomo, penelitian tersebut mampu menampilkan suasana kampus, dan memberikan informasi letak gedung [6], sedangkan penelitian yang dilakukan oleh Miftakhul Huda dkk berhasil memudahkan masyarakat umum untuk memperoleh informasi seputar Kampus Universitas Wahid Hasyim [7].

Penelitian ini bertujuan untuk memberikan informasi tentang lingkungan kampus Politeknik Elektronika Negeri Surabaya (PENS) secara keseluruhan dengan mengimplementasikan teknologi virtual reality yang dapat diakses melalui aplikasi browser. Keunggulan aplikasi yang dibuat dalam penelitian ini dibandingkan dengan penelitian sebelumnya adalah data yang diolah menggunakan gambar panorama $360^{\circ}$ yang dihasilkan dari kamera 360, sehingga tidak perlu proses stitching untuk menggabungkan gambar dan gambar panorama yang dihasilkan lebih nyata. Keunggulan lainnya dari aplikasi ini menggunakan animasi transisi pergesaran pada saat navigasi serta dilengkapi dengan fitur radar. Aplikasi ini diharapkan dapat dimanfaatkan sebaik-baiknya untuk memberikan kemudahan bagi mahasiswa atau pengunjung untuk mencari ruangan/laboratorium/fasilitas lain yang dimiliki oleh PENS dengan lebih jelas dan nyata.

\section{METODE PENELITIAN}

Agar tujuan penelitian dapat tercapai dengan baik diperlukan perencanaan dengan baik melalui tahapan penelitian. Adapun tahapan yang digunakan pada penelitian ini ditampilkan pada Gambar 1.

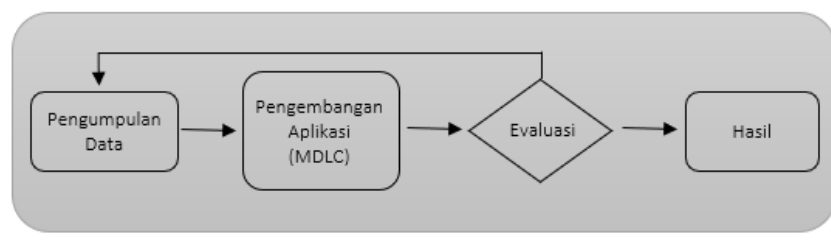

Gambar 1. Alur Penelitian

\subsection{Metode Pengumpulan Data}

Pada penelitian ini alur yang pertama adalah data dikumpukan dengan cara sebagai berikut:

\subsubsection{Wawancara}

Pengumpulan data dilakukan wawancara langsung dengan narasumber diantaranya, Bagian Humas PENS, Bagian Kemahasiswaan dan Kepala Departemen Teknologi Multimeda Kreatif. Wawancara ini bertujuan untuk menggali informasi dan mengetahui permasalahan yang ada serta untuk menentukan fitur apa saja yang akan diberikan di dalam aplikasi.

\subsubsection{Studi Pustaka}

Studi literatur pembuatan aplikasi virtual tour ini dilakukan dengan pencarian terkait penelitian pembuatan virtual tour dan pengumpulan data dilakukan dengan cara menganalisa literatur dari referensi jurnal yang mendukung.

\subsection{Pengembangan Aplikasi}

Pada bagian pengembangan aplikasi sistem dilakukan dengan metode Multimedia Develompent Life Cycle (MDLC), dimana metode ini memiliki 6 tahapan yaitu concept, design, material collecting, assembly, testing dan distribution [8] [9]. Langkah-langkah MDLC dalam penelitian ini sebagai berikut:

\subsubsection{Concept (Konsep)}

Pada tahap concept dijelaskan penjabaran tentang ide pembuatan aplikasi, yaitu memberikan informasi kepada mahasiswa tentang lingkungan kampus, serta aplikasi disajikan dalam bentuk web agar mudah diakses oleh pengguna desktop dan mobile. Konsep pembagian project dilakukan untuk merancang lokasi mana saja yang akan ditampilkan kedalam aplikasi virtual tour yang akan dibuat berdasarkan gedung yang dimiliki PENS. 


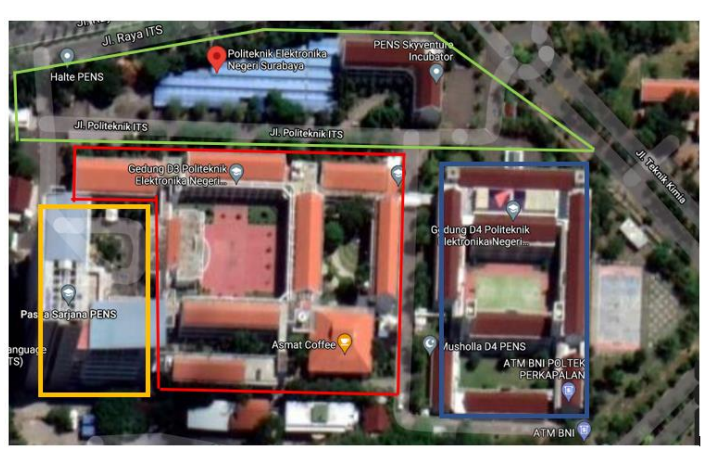

Gambar 2. Denah Kampus PENS

Dari denah pada Gambar 2 dapat dijelaskan, dengan luas lahan $49.200 \mathrm{~m}^{2}$ dan memiliki 4 gedung utama, maka penelitian ini membagi project aplikasi menjadi 4 yaitu project Gedung D3 (merah), project Gedung D4 (biru), project Gedung Pasca (kuning) dan project Fasum (hijau). Dalam tahap concept juga ditentukan titik lokasi untuk pengambilan gambar panorama $360^{\circ}$.

\subsubsection{Design (Desain)}

Pada tahap design pembuatan aplikasi virtual tour, penelitian ini merancang layout antarmuka website landing page menggunakan aplikasi Balsamiq seperti terlihat pada Gambar 3. Perancangan antarmuka ini bertujuan untuk memudahkan pengguna dalam menjalankan aplikasi virtual tour.

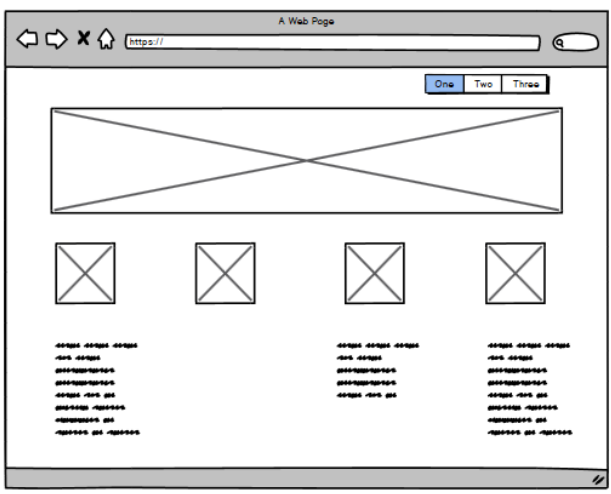

Gambar 3. Rancangan Landing Page

\subsubsection{Material Collecting (Pengumpulan Materi)}

Tahap material collecting dilakukan dengan melakukan pengambilan gambar panorama di setiap titik lokasi yang sudah ditentukan dalam tahap concept dengan menggunakan kamera 360. Gambar panorama $360^{\circ}$ yang dihasilkan dapat dilihat pada Gambar 4.

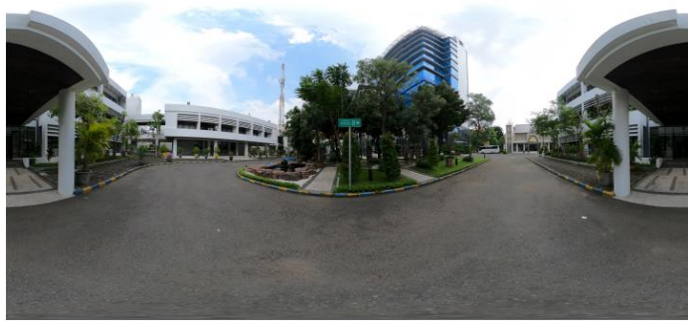

Gambar 4. Hasil Gambar Panorama dari Kamera $360^{\circ}$

\subsubsection{Assembly (Penyusunan)}

Tahap assembly dilakukan proses membuat aplikasi virtual tour dengan menggunakan aplikasi 3DVista. Gambar panorama yang diperoleh dari proses material collecting diolah dan dibuat titik (hotspot), dimana titik ini sebagai tombol navigasi yang digunakan untuk berpindah tempat menuju titik yang lain. Selain untuk berpindah tempat hotspot juga digunakan sebagai tombol untuk menampilkan video atau kumpulan gambar (album photo). Pembuatan hostspot di dalam aplikasi 3DVista dapat dilihat pada Gambar 5.

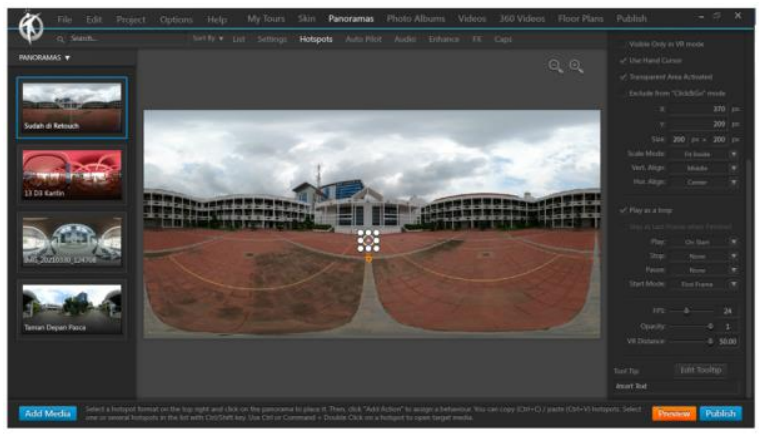

Gambar 5. Tampilan Aplikasi 3DVista

\subsubsection{Testing}

Setelah selesai tahap pembuatan aplikasi dilakukan tahap testing. Pada tahap pengujian ada dua bagian, bagian pertama menguji fitur-fitur yang ada di dalam aplikasi, untuk melihat kemungkinan adanya kesalahan, seperti terlihat pada Gambar 6, dimana sistem dapat menampilkan kumpulan gambar, pengujung dapat menekan tombol panah kanan atau kiri untuk melihat gambar selanjutnya. Sedangkan bagian pengujian yang kedua dilakukan secara black box testing dijelaskan pada sub bab 2.3.

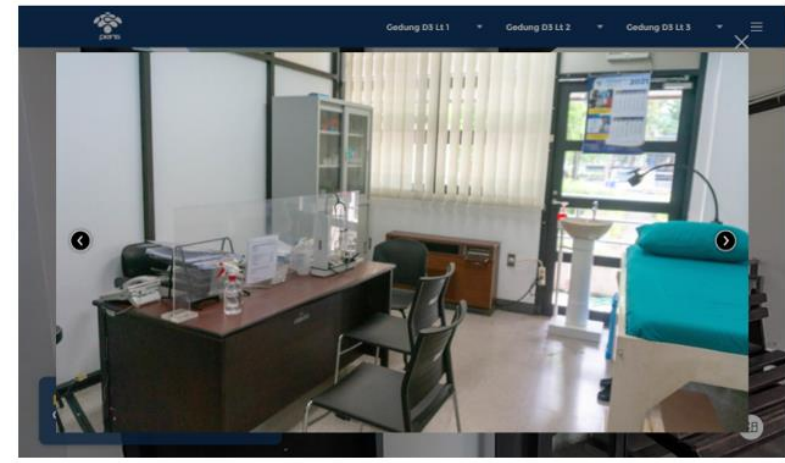

Gambar 6. Pengujian Fitur menampilkan Kumpulan Gambar

\subsubsection{Distribution}

Tahap distribution adalah tahap akhir dalam metode MDLC setelah memastikan semuai fungsi berjalan dengan semestinya sehingga aplikasi layak untuk didistribukasikan. Aplikasi virtual tour berhasil diimplementasikan dan dapat diakses dengan laman http://virtualtour.pens.ac.id/ seperti terlihat pada Gambar 7. 


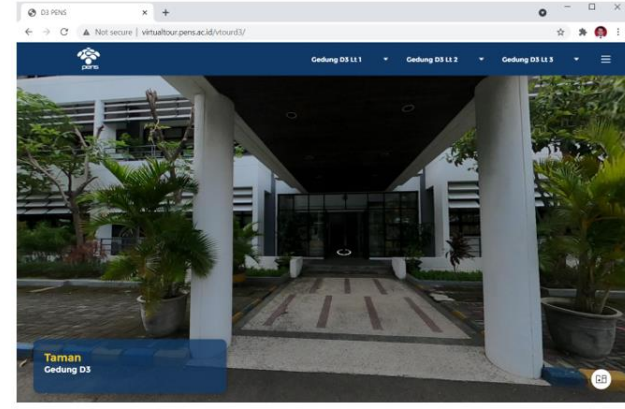

Gambar 7. Tampilan Aplikasi Virtual Tour Project Gedung D3

\subsection{Hasil Pengujian}

Pengujian aplikasi virtual tour menggunakan black box testing. Teknik pengujian black box banyak digunakan untuk menguji perangkat lunak. Tujuan dari pengujian ini adalah memastikan apakah aplikasi yang dibuat berjalan dengan baik atau tidak [11]. Hasil pengujian fungsional dijabarkan pada Tabel 1, dari tabel tersebut dapat dilihat bahwa aplikasi Virtual Tour berhasil dibuat, dan pengguna dapat menggunakan fitur-fitur yang disediakan oleh aplikasi.

Tabel 1. Hasil Pengujian Fungsionalitas

\begin{tabular}{llc}
\hline \multicolumn{1}{c}{ Pengujian } & \multicolumn{1}{c}{ Hasil Pengujian } & Kesimpulan \\
\hline $\begin{array}{l}\text { Dapat mengakses } \\
\text { website virtual tour }\end{array}$ & $\begin{array}{l}\text { Dapat mengakses } \\
\text { sesuai domain }\end{array}$ & Berhasil \\
$\begin{array}{l}\text { Menu pada halaman } \\
\text { landing page }\end{array}$ & $\begin{array}{l}\text { Sesuai dengan project } \\
\text { yang dipilih }\end{array}$ & Berhasil \\
$\begin{array}{l}\text { Menu pada virtual } \\
\text { tour }\end{array}$ & $\begin{array}{l}\text { Sesuai dengan gambar } \\
\text { panorama yang dipilih }\end{array}$ & Berhasil \\
$\begin{array}{l}\text { Dapat mengganti } \\
\text { sudut pandang }\end{array}$ & $\begin{array}{l}\text { Sesuai dengan tombol } \\
\text { drag pengguna }\end{array}$ & Berhasil \\
Tombol hotspot & $\begin{array}{l}\text { Berfungsi dengan } \\
\text { mengganti gambar } \\
\text { panorama yang dipilih }\end{array}$ & Berhasil \\
Fungsi tombol zoom & Bekerja sesuai fungsi & Berhasil \\
Fitur informasi & $\begin{array}{l}\text { Sesuai dengan gambar } \\
\text { panorama }\end{array}$ & Berhasil \\
Fitur floorplan & $\begin{array}{l}\text { Sesuai dengan lokasi } \\
\text { riil }\end{array}$ & Berhasil \\
\hline
\end{tabular}

\section{HASIL DAN PEMBAHASAN}

3.1 Pengambilan Gambar Panorama $360^{\circ}$

Pengambilan gambar atau pemotretan dilakukan pada saat kondisi cerah agar menghasilkan gambar yang baik, dan tidak memberikan efek bayangan. Kamera yang digunakan dalam penelitian ini adalah GoPro Max $360^{\circ}$, seperti terlihat pada Gambar 8.

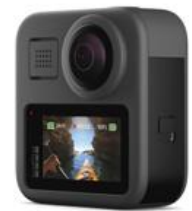

Gambar 8. Kamera GoPro Max 360
Kamera tersebut dikontrol menggunakan smartphone yang dilengkapi dengan aplikasi GoPro Quick (Android), tampilan dari aplikasi tersebut dapat dilihat pada Gambar 9. Pada saat pengoperasian kamera ini, fitur Wi-Fi pada smartphone harus dijalankan, setelah kamera dijalankan, kamera akan mendeteksi secara otomatis keberadaan smarthphone. Selain itu, fitur location pada smartphone juga harus dijalankan saat mengoperasikan kamera ini. Hasil pemotretan tersimpan di dalam memori penyimpanan $S D$ card yang ada didalam kamera GoPro.

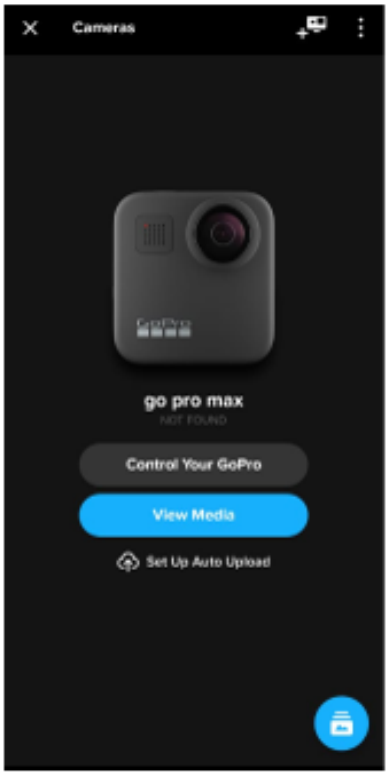

Gambar 9. Tampilan Aplikasi GoPro Quick

Pada Gambar 10 dapat dijelaskan kondisi saat pengambilan gambar. Kamera diletakkan pada tripod dan tingginya diatur sejajar dengan pandangan mata manusia berdiri normal yaitu sekitar antara $165-170 \mathrm{~cm}$ dari lantai, sehingga gambar panorama yang dihasilkan sama seperti manusia melihat berdiri normal.

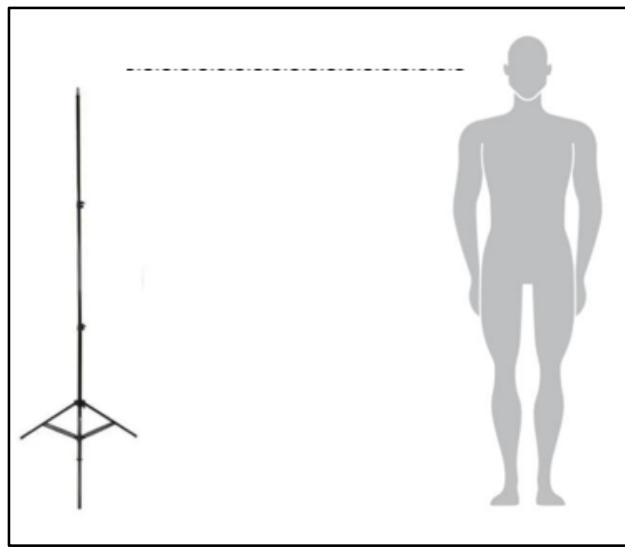

Gambar 10. Proses Pengambilan Gambar/Pemotretan

Hasil pengambilan gambar panorama dapat dilihat dari Tabel 2. Ukuran data dari tiap gambar panorama sangat besar, sehingga sebagai pertimbangan maka lokasi yang diambil gambar hanya sebagian dari fasilitas kampus PENS. 
Tabel 2. Hasil Pengumpulan Data

\begin{tabular}{lcc}
\hline \multicolumn{1}{c}{ Project } & Jumlah Gambar & $\begin{array}{c}\text { Ukuran File } \\
\text { (MB) }\end{array}$ \\
\hline Gedung D3 & 151 & 666 \\
Gedung D4 & 119 & 536 \\
$\begin{array}{l}\text { Gedung } \\
\text { Pascasarjana }\end{array}$ & 108 & 326 \\
Fasilitas Umum & 84 & 628 \\
\hline
\end{tabular}

\subsection{Pembuatan Aplikasi}

Tahap pertama dalam pembuatan aplikasi yaitu proses retouching gambar panorama $360^{\circ}$, yaitu proses menghapus objek tripod pada gambar yang telah diambilkan. Pada Gambar 11 dapat dijelaskan, gambar disebelah kiri adalah gambar panornama $360^{\circ}$ yang belum di retouch, dimana objek tripod masih terlihat, sedangkan gambar disebelah kanan adalah hasil retouch.
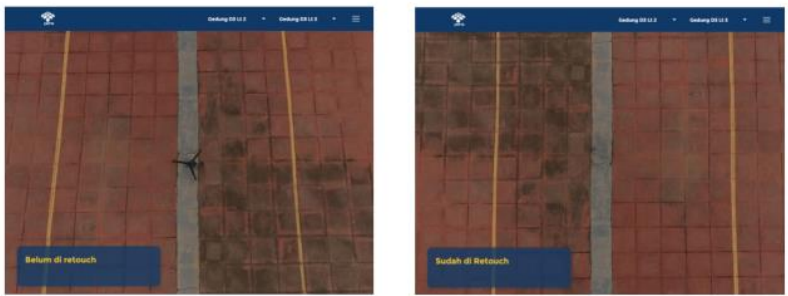

Gambar 11. Tahap Retouching Gambar Panorama $360^{\circ}$

Tahap yang kedua adalah membuat aplikasi virtual tour menggunakan aplikasi 3DVista. Langkah pertama pada saat membuat aplikasi virtual tour menggunakan aplikasi 3 DVista adalah memilih skin yang akan digunakan pada project yang akan dibuat. Tampilan menu skin dapat dilihat pada Gambar 12. Pemilihan warna skin dapat diatur sesuai dengan kebutuhan.

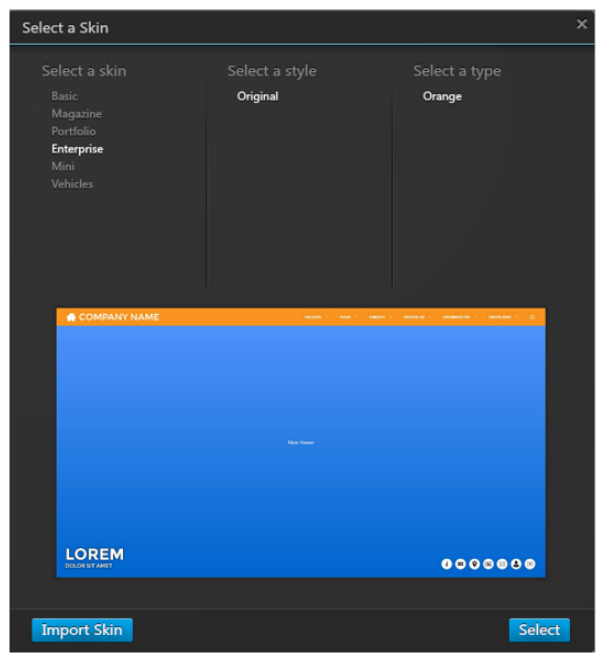

Gambar 12. Memilih Skin
Langkah kedua seperti terlihat pada Gambar 13 yaitu tampilan untuk memasukkan gambar yang sudah di retouch (Import Panorama).

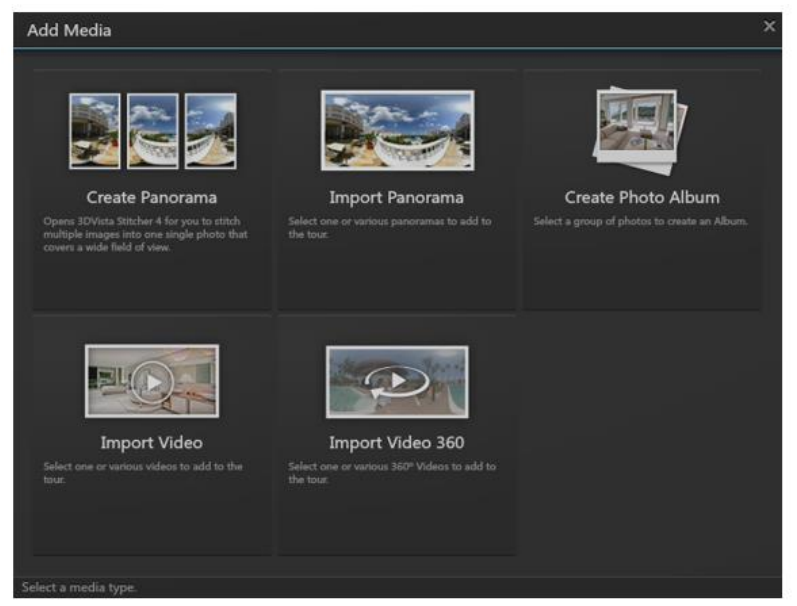

Gambar 13. Import Gambar Panorama

Aplikasi 3DVista juga menyediakan fitur create panorama, fitur ini digunakan untuk penjahitan gambar (image stitching) untuk menghasilkan gambar panorama.

Langkah ketiga adalah membuat titik hotspot, terdapat pilihan ikon untuk penggunaan hostspot, seperti ikon arrow, door, round dll [10] seperti terlihat pada Gambar 14. Pemilihan ikon ini disesuaikan dengan kebutuhan agar tidak membingungkan bagi pengguna. Ikon panah digunakan untuk titik menuju gambar panorama selanjutnya, sedangkan ikon pintu pintu digunakan untuk memasuki ruangan.

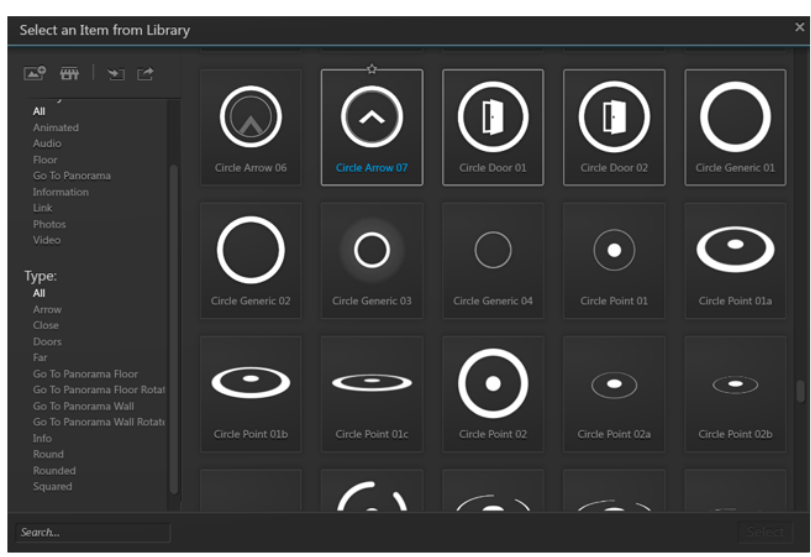

Gambar 14. Pemilihan Icon Hotspot

Setelah menentukan titik hotspot dan pemilihan ikon, langkah keempat adalah memberikan aksi (add action) di setiap titik hotspot. Terdapat beberapa aksi yang disediakan oleh Aplikasi 3DVista diantaranya open panorama, open album, open URL dll. Pilihan aksi terdapat pada Gambar 15. 


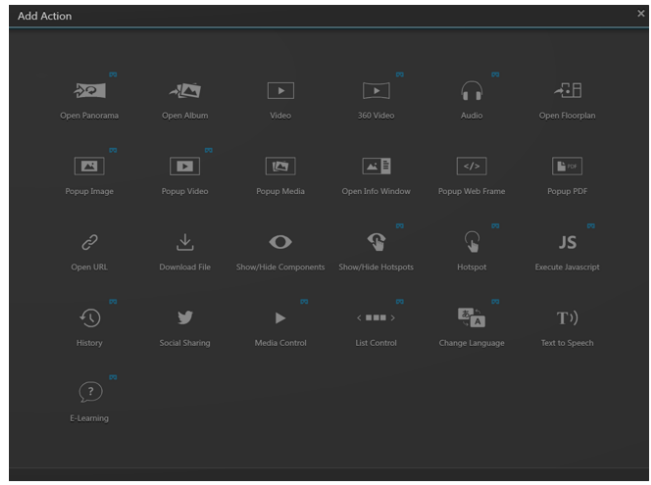

Gambar 15. Pemilihan Add Action

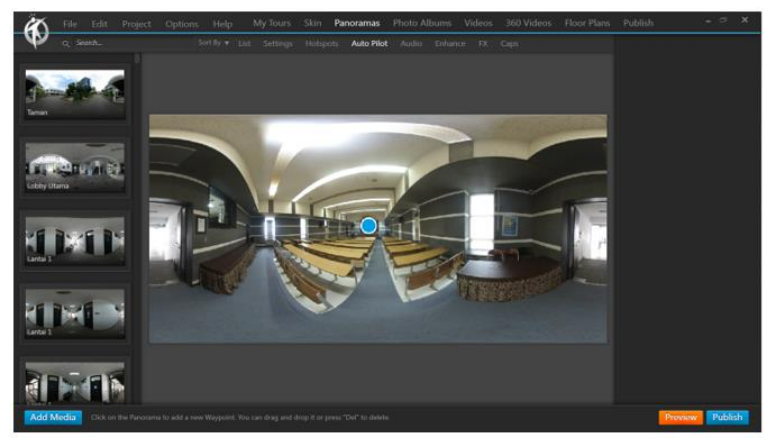

Gambar 16. Fitur Auto Pilot

Fitur auto pilot digunakan untuk tampilan awal ketika gambar panorama $360^{\circ}$ ditampilkan pertama kali. Fitur ini ditunjukkan pada Gambar 16 terdapat titik berwarna biru, sebagai titik tampilan awal gambar panorama. Langkah kelima adalah membuat fitur floorplan seperti ditunjukkan pada Gambar 17 merupakan fitur untuk menampilkan peta lokasi dalam bentuk 2D, dimana peta tersebut diberi titik (hotspot) berwarna orange, apabila titik tersebut diklik maka aplikasi akan menampilkan gambar panorama di lokasi yang dipilih tersebut. Tedapat fitur radar area berwarna biru muda, saat gambar panorama diarahkan ke kanan atau ke kiri, maka radar akan mengikuti area yang terlihat sesuai dengan peta.

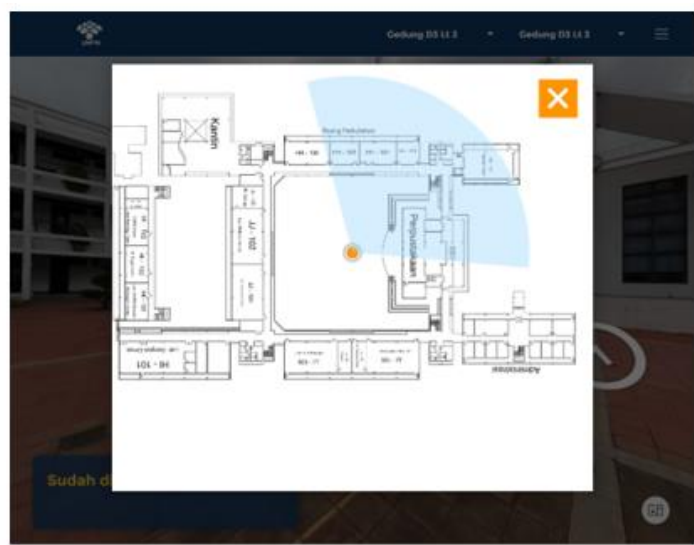

Gambar 17. Fitur Floorplan

Langkah keenam adalah membuat fitur photo album seperti ditunjukkan pada Gambar 18. Fitur ini menampilkan beberapa kumpulan gambar dalam bentuk portrait. Aplikasi akan menampilkan kumpulan gambar tersebut dalam bentuk album.

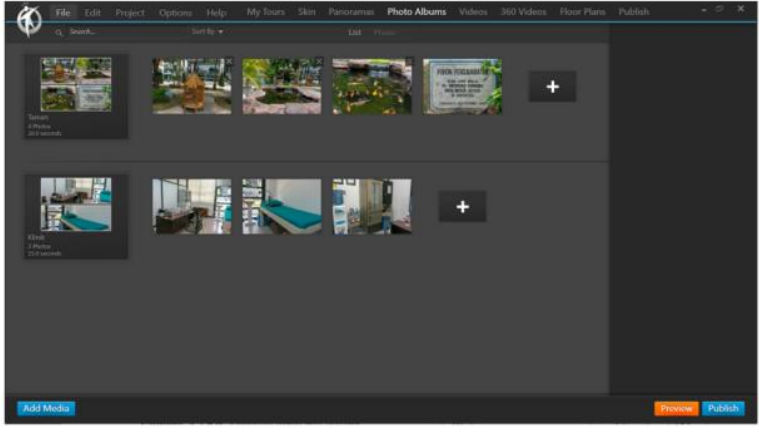

Gambar 18. Fitur Photo Album

Langkah terakhir dalam pembuatan aplikasi virtual tour di dalam aplikasi 3DVista yaitu publish. Aplikasi akan secara otomatis membuat file website dengan bahasa pemrograman Javascript dan HTML, sehingga file-file tersebut siap diunggah ke dalam server. Bentuk file tersebut dapat dilihat pada Gambar 19.

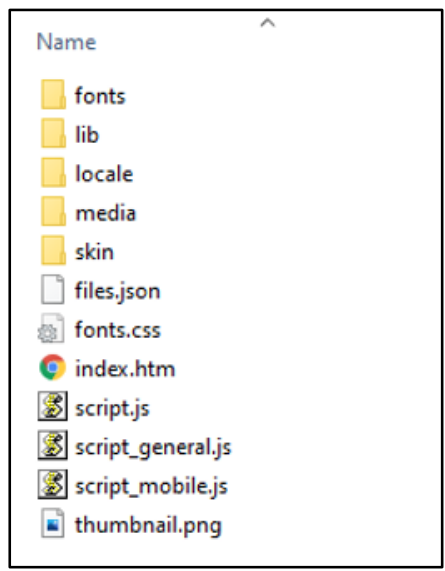

Gambar 19. File Hasil Publish

\subsection{Tampilan Aplikasi Virtual Tour}

Aplikasi virtual tour ini memiliki tampilan awal website atau biasa disebut dengan landing page sesuai dengan rencana yang telah dibuat, seperti terlihat pada Gambar 20, dimana pengunjung diberikan pilihan untuk dapat memilih project mana yang diinginkan. Ada empat pilihan project, diantaranya project Gedung D3, project D4, project Pascasarjana dan project Fasilitas Umum. Di bagian atas terdapat navbar menu dengan text berwarna putih

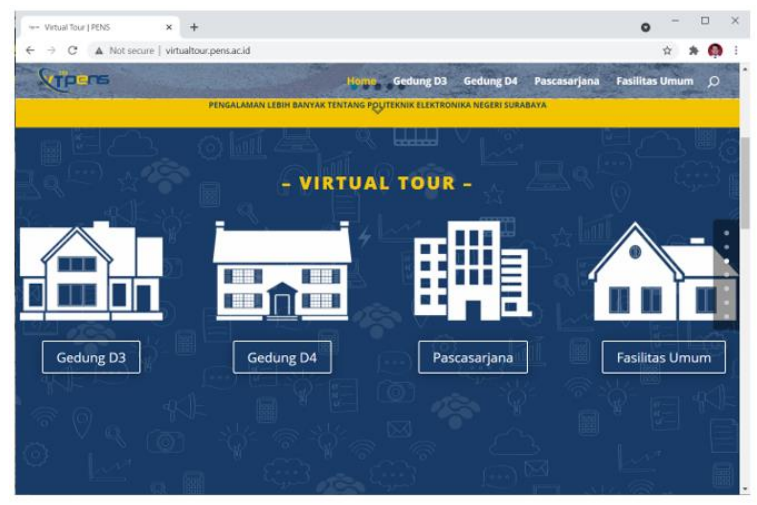

Gambar 20. Tampilan Landing Page Aplikasi Virtual Tour PENS 
Tampilan navbar disetiap project menampilkan menu lokasi gedung, seperti Lantai 1, Lantai 2 dan Lantai 3, dimana di setiap lantai terdapat fasilitas laboratorium yang dimiliki oleh PENS. Di setiap gambar panorama yang ditampilkan oleh sistem, terdapat keterangan di bagian sisi kiri bawah seperti terlihat pada Gambar 21.

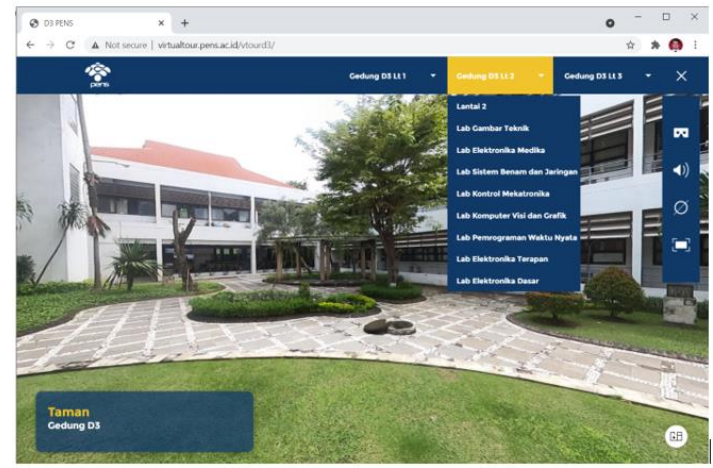

Gambar 21. Tampilan Project Gedung D3 Virtual Tour PENS

Aplikasi Virtual Tour Kampus PENS menyediakan fitur floorplan dengan radar. Gambar 22 dapat dijelaskan, pengunjung dapat menggerakan mouse ke kanan dan ke kiri dan secara otomatis radar dan gambar panorama akan mengikuti pergerakan mouse tersebut.

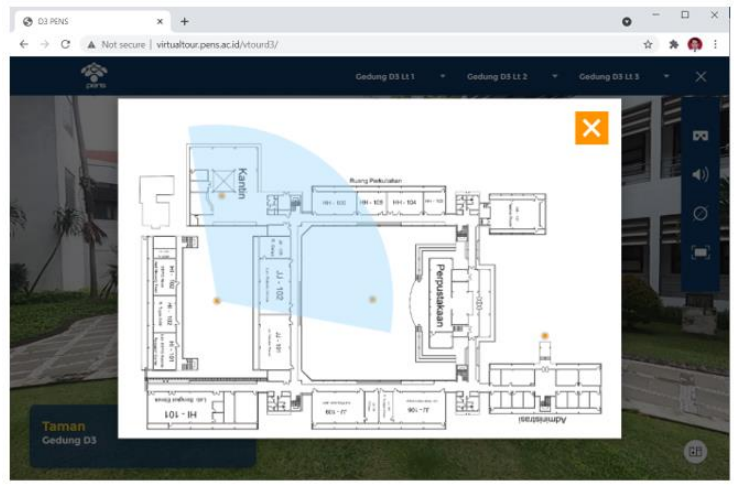

Gambar 22. Tampilan Fitur Floorplan dengan Radar

Terdapat fitur untuk menampilan informasi yang ada di gambar panorama, misalnya seperti Gambar 23, dimana pengunjung dapat melihat ikon informasi, maka aplikasi Virtual Tour akan menampilkan pop-up informasi terkait lokasi tersebut.

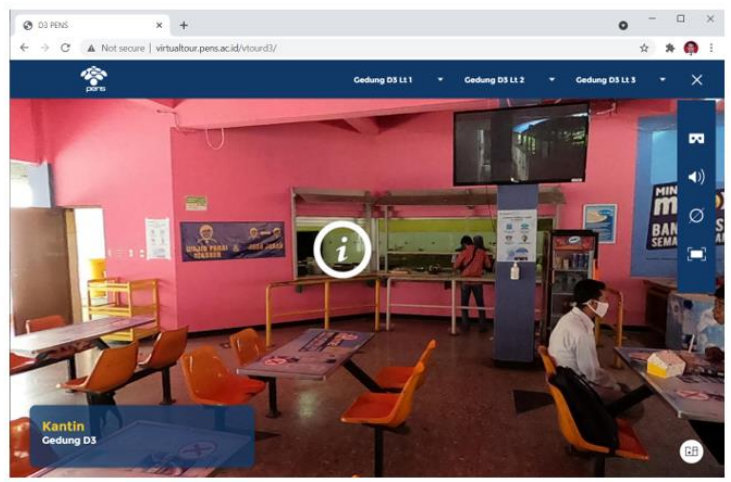

Gambar 23. Tampilan Fitur Information

\section{KESIMPULAN}

Berdasarkan hasil penelitian yang sudah dilakukan serta melakukan pengujian, aplikasi Virtual Tour berbasis website yang dibuat dibagi menjadi 4 project, sesuai dengan gedung yang dimiliki oleh PENS. Aplikasi dapat diakses menggunakan web browser dan mampu menampilkan informasi tentang lingkungan kampus letak gedung/ruang /laboratorium/fasilitas lainnya dalam bentuk panorama $360^{\circ}$ dengan memanfaatkan multi image panorama $360^{\circ}$ dan perpindahan antar hotspot menggunakan animasi berjalan. Aplikasi ini membutuhkan pengembangan lebih lanjut misalnya penggunaan fitur video $360^{\circ}$ dan fitur pemandu yang menjelasan bagian-bagian tertentu dalam bentuk suara, sehingga pengunjung lebih interaktif dalam menerima informasi yang diberikan oleh sistem.

\section{Ucapan Terima Kasih}

Penulis mengucapkan terima kasih kepada jajaran Manajemen Politeknik Elektronika Negeri Surabaya (PENS) dan Kepala Departemen Teknologi Multimedia Kreatif yang telah memberikan dukungan penuh kepada penulis, serta semua pihak yang ikut menyukseskan penelitian ini.

\section{DAFTAR PUSTAKA}

[1] S. Highton, "Papper of Virtual Reality Photography Creating Panoramic and Object Images," Library of Congress, 2010.

[2] M. Dengzhe, "Virtual Reality \& Augmented Reality in Industry," 2011.

[3] P. Alexander, "Pembentukan Citra Panorama $360^{\circ}$ dengan Image Mosaicing," J. Inform., vol. 2, no. 1, pp. 5-5, 2001, doi: 10.9744/informatika.2.1.pp.1-5.

[4] R. Bastian, N. Budi, M. B. Wenas, F. T. Informasi, U. Kristen, and S. Wacana, "Perancangan Virtual Tour Kampus I UKSW," Andharupa, vol. 4, no. 1, pp. 51$65,2018$.

[5] R. Nulhakim and E. W. Hidayat, "Virtual Tour Pengenalan Area Universitas Siliwangi dengan Multi Image Panorama $360^{\circ}$ berbasis Web," Sci. Artic. Informatics Students, vol. 3, no. 2, pp. 145-151, 2019.

[6] A. Choiron, "Aplikasi Virtual Tour Dinamis pada Universitas Dr. Soetomo Surabaya berbasis Web," J. Inf., vol. 2, no. 2, 2017, doi: 10.25139/ojsinf.v2i1.406.

[7] M. Huda and M. Mustagfirin, "Virtual Tour sebagai Media Informasi Kampus Universitas Wahid Hasyim Semarang," J. Inform. dan Rekayasa Perangkat Lunak, vol. 1, no. 2, pp. 79-81, 2019, doi: 10.36499/jinrpl.v1i2.2950.

[8] E. E. Setianto, Wahyu; Risqiati; Agung, Hari; Purnama, "Implementasi Virtual Tour sebagai Media Informasi Deswita Pandansari Berbasis Web," J. Ris. Inov. dan Teknol., vol. 4, no. 2, pp. 22-30, 2019. 
[9] A. Adityo, "Pembuatan Virtual Reality Tour dengan Metode Gambar Panorama untuk Kampus Fakultas Teknik Universitas Hasanuddin," Univ. Nusant. PGRI Kediri, vol. 01, pp. 1-7, 2017, [Online]. Available: http://www.albayan.ae.

[10] 3Dvista, "3DVista Virtual Tour Suite Quick Guide," 3DVista Espana S.L., 2014.

[11] M. Mardainis, M. Arifin, R. Rahmaddeni, and Y. Efendi, "Virtual Tour Interaktif 360 Derajat menggunakan Teknik Image Stitching sebagai Media Informasi Kampus STMIK Amik Riau," Digit. Zo. J. Teknol. Inf. dan Komun., vol. 11, no. 2, pp. 209-222, 2020, doi: 10.31849/digitalzone.v11i2.4265. 